\title{
Jogo de Encontros: a experiência do Personne
}

\author{
Fernando Iazzetta \\ Universidade de São Paulo - USP \\ iazzetta@usp.br \\ Rodolfo Caesar \\ Universidade Federal do Rio de Janeiro - UFRJ \\ José Augusto Mannis \\ Universidade Estadual de Campinas - UNICAMP \\ ja.mannis@uol.com.br \\ Lílian Campesato \\ Universidade de São Paulo - USP \\ lilicampesato@gmail.com \\ Alexandre Fenerich \\ Universidade Federal de Juiz de Fora - UFJF \\ fenerich@gmail.com
}

\section{Começando}

Este texto traz uma reflexão acerca do Personne, uma reunião de artistas que mantêm um vínculo a partir das afinidades pessoais e musicais de seus integrantes. Os trabalhos realizados operam num terreno pouco sedimentado, envolvendo experiências com o repertório da música contemporânea e, especialmente, com a articulação dessa música com outras artes. Embora cada performance apresente uma nova configuração, elas evidenciam certos aspectos poéticos comuns, mesmo sem delimitar um território específico. Um traço de informalidade nas criações do grupo revela uma postura que é, ao mesmo tempo, despretensiosa e crítica.

O Personne teve início com um projeto ambicioso de realizar uma versão instrumental da obra Symphonie pour un Homme Seul (1950) de Pierre Schaeffer e Pierre Henry. Paradigmática em sua concepção acusmática, a transcriação da Symphonie para um grupo de performance instrumental poderia suscitar - e, de fato, suscitou - uma série de questionamentos a respeito da natureza dessa versão. Entretanto, a realização da Symphonie serviu para expressar o desejo de realizar um projeto musical mirando sua musicalidade e sua potencialidade de 
atingir as pessoas que iriam assisti-lo, deixando assim para um segundo plano qualquer preocupação com o engajamento que frequentemente se observa na conformação da composição musical aos seus devidos espaços (a sala de concerto, a análise musicológica, a filiação a estilos e escolas, etc.).

O projeto da versão instrumental Symphonie, apresentado ao público em 2010 no Parque Lage no Rio de Janeiro, parece ter deixado uma marca profunda neste grupo de músicos, a ponto de gerar estímulo para que novos trabalhos fossem realizados. Esses novos trabalhos se sucederam nos anos seguintes envolvendo performances que poderiam ser rotuladas como "audiovisuais" em função dos materiais que utilizaram, mas que de alguma forma dissolvem os contornos mais ou menos bem conhecidos e estabelecidos do que chamamos de música, cinema e performance.

Os textos expostos a seguir são fruto das trocas intensas que cinco artistas do Personne realizaram dentro e fora do palco. Neles não há pretensão musicológica ou acadêmica. Antes, buscam expor o que parece ser mais significativo na prática musical do grupo, a sua poética, a partir das impressões individuais de alguns de seus participantes. A opção por uma abordagem ensaística e pelo tom pessoal dos textos não é casual. Ao contrário, essa opção reforça uma postura ética e política, que claramente contamina a poética do grupo. A proposta do Personne é fruto da descrença numa série de valores que constituem uma base para a produção da chamada música contemporânea e para a construção dos discursos que a legitimam. Este cenário, muito consoante com o projeto modernista de criar uma tradição do novo e uma mania de teorização da arte (Compagnon, 2010, p. 12), mostra um tal esgotamento que se torna necessária a busca por alternativas. Em primeiro lugar, é preciso encontrar rotas de fuga que evitem as grandes vias traçadas pelo academicismo e pela institucionalização da música contemporânea. Desde que Milton Babbitt assumiu publicamente que a música da vanguarda estaria além do homem comum e que a universidade teria a obrigação de abrigar essa música feita por especialistas e para especialistas (Babbitt, 1958), parece haver uma acomodação crescente das produções musicais no porto seguro das instituições. Não se trata aqui de fazer uma crítica rasa à Instituição em geral, já que parecem evidentes os aspectos positivos da associação entre o fazer artístico e setores formais da sociedade como a universidade, os sistemas de fomento ou a industria criativa. A crítica refere-se ao desequilíbrio que ocorre quando a arte 
precisa atender cegamente às demandas dessas instituições, tornando-se, ela mesma, institucional. Parece que só recentemente este cenário começa a ser questionado abertamente no âmbito acadêmico, como na análise seminal que Georgina Born faz sobre a institucionalização da vanguarda a partir de uma etnografia do IRCAM, instituição cuja "tentativa de institucionalizar a criatividade representa ela mesma uma nova iniciativa na institucionalização da música" (Born, 1995, p. 2).

Mas, como deixar de ser institucional, mesmo fazendo parte da academia? Como lidar com a complexidade do pensamento e com a instabilidade da criação artística, sem esquecer da conexão entre a arte e as pessoas? Como fazer música sem a obrigação de cumprir os requisitos socioculturais e mercadológicos que geralmente a legitimam? Como levar a sério o trabalho artístico e ao mesmo tempo divertirse com ele? Como transitar com liberdade entre territórios de sons, imagens e gestos, cujos nomes que conhecemos - música, eletroacústica, cinema, improvisação - já não conseguem dar conta? Enfim, como ignorar preceitos como autoria, virtuosismo e maestria, tão caros à produção da música de concerto, e ainda assim acreditar na potência poética e estética do que fazemos?

Os textos que se seguem não respondem a essas questões. Tampouco o trabalho do Personne se coloca como qualquer tipo de resposta. Ao contrário, tanto os textos, em seu caráter reflexivo e pessoal, quanto o próprio trabalho do grupo, propõem um deslocamento dos nossos hábitos em relação à produção musical. Não se trata de desacreditar nos territórios em que estamos acostumados a nos expressar, como o concerto de música no caso da produção artística, ou o artigo acadêmico, no caso da reflexão sobre essa produção. Os textos buscam mostrar que é possível fazer e pensar a música sem o peso da teorias e sem o compromisso com formas que, talvez há muito tempo, já não nos digam mais respeito.

\section{Quem somos, de onde viemos, para onde vamos? (Rodolfo Caesar)}

O convite para escrever algumas linhas sobre as atividades do grupo, de que tenho participado em diversas apresentações mais ou menos recentes, é algo que me faz manifestar profunda gratidão - ao mesmo tempo que martela a expressão 'que tarefa ingrata!' O que tenho para dizer sobre aquilo que se pretendeu criar dentro 
da esfera de um indizível? (Não, não se trata desse emudecedor 'inefável', que se quer atribuir à música para inibir qualquer discussão). O indizível do nosso trabalho não é deliberado, vem por efeito colateral, simplesmente porque não foi classificado de antemão: e acredito que nem nos empenhemos para que o seja. As atividades mais recentes do nosso grupo demonstram, na minha opinião, maior empenho no fazer do que em classificar ou preparar um discurso legitimador para o que se faz ou fez. Essa fluidez explica minha relutância para falar.

A começar por seu 'nome', que não está aí para ser um nome de marca, sendo apenas um facilitador para que produtores, organizadores e divulgadores de atividades que envolvam o grupo tenham algo a referir. Tudo nele pode mudar, assim como já variou seu efetivo, que da primeira vez se apresentou com oito, depois com seis, uma vez com três, e duas com quatro músicos. A escolha do nome não é definitiva e já traz o desconforto de não desfrutarmos do nosso idioma. Recai sobre o duplo-sentido da palavra que significa pessoa - com a origem no latim persona - aquela máscara que, enquanto amplificava os sons dos atores nos palcos de anfiteatros, retirava os traços visíveis de sua individualidade. Em francês, de certa maneira, fica mais interessante porque o vazio perdura, personne é ninguém, é a máscara porta-voz sem alguém a portá-la. (E cá estou eu, diante da ingrata tarefa de portar a voz de personne!) Entretanto, como não temos expectativas que nos determinem ao uso de um nome de marca para fixarmos nosso lugar na mente do 'público', ou do mercado, podemos mudar tudo a qualquer minuto. Daí que nós, mais do que um grupo de música contemporânea, somos um encontro.

Nosso encontro, então, é de músicos que gostam de tocar juntos. Uma vez que nossos idiomas comuns mais aproximados não são o samba-de-raiz, o choro, o jazz, o funk, o rock. Tocamos coisas mais alinhadas às nossas experiências instrumentais e eletroacústicas, de forma mais-ou-menos improvisada. A despretensão é tão fundamental que nem serve de fundamento, daí que nem mesmo a improvisação pura possa ser a nossa meta. Podemos ensaiar também, até porque gostamos disso.

A origem dessa dinâmica aconteceu em 2010 quando o primeiro efetivo foi reunido - Alexandre Fenerich, Doriana Mendes, Fernando Iazzetta, Janete El Haouli, José Augusto Mannis, Lilian Campesato, Michelle Agnes e eu - para realizar um velho projeto: o de recriar, ao vivo, a 'Symphonie pour un homme seul', de Pierre Henry 
e Pierre Schaeffer ${ }^{1}$. A esse grupo somou-se Caique Bellaver, que havia ajudado Mannis no praticamente insano trabalho de 'redução' da Symphonie: trazer para a notação gráfica o que tinha sido feito eletroacusticamente, ou seja, uma transcrição teoricamente contrária ao acusmatismo que essa música propôs quando de sua estreia em 1950.

Desde os anos noventa sonhávamos com essa oportunidade - a amiga Laura di Pietro e eu - chutando cascalho em caminhadas nas Paineiras, reclamando do isolamento condicionado pela composição e pela realização eletroacústica em concerto. Acho, então, que a noção mais adequada que veio se configurando desde o início desse texto é principalmente a seguinte: um encontro de afinidades, um desejo de compartilhamento.

Depois do evento no Parque Lage nos reunimos, no ano seguinte, no EIMAS [Encontro Internacional de Música e Arte Sonora] em Juiz de Fora, sem Caíque e Doriana, para uma apresentação acompanhando a projeção de um trecho do filme Limite, de Mário Peixoto, em sessão completada com trabalhos mais individualizados de duos que, como tais, elaboraram separadamente. Para mim permaneceu a sensação de ter sido um belo encontro, embora dessa vez diante de uma plateia especular: acadêmica e 'especialista'. A isso sucedeu um período de quase dois anos sem qualquer atividade.

Em final de 2013, a convite da Escola de Artes Visuais do Parque Lage para realizar a curadoria de sua tradicional sessão do Cine Lage, três de seus sete músicos iniciais tocaram juntos, sem sequer lembrarem - por absoluta falta de necessidade - que poderiam acionar a 'persona'. Compusemos, ao vivo - Alexandre Fenerich, Lilian Campesato e eu - uma nova trilha musical para Dreams that money can buy (1947), filme de Hans Richter. Em 2014 o encontro aconteceu mais uma vez: outra vez no Cine Lage do Parque Lage e, no dia seguinte, nos Encontros Carbônicos do Largo das Artes, no Rio de Janeiro.

Ambos os eventos com os três do efetivo do ano anterior, mais Fernando Iazzetta. O primeiro programa foi igual ao do ano anterior, o seguinte sendo mais diversificado: um curta de Hans Richter de 1926, um trecho de Twin Peaks (1991) de David Lynch e contribuições individuais de membros do grupo.

\footnotetext{
${ }^{1}$ Um registro da transcriação Symphonie na apresentação realizada no Parque Lage, Rio de Janeiro, pode ser visto em: https://www.youtube.com/watch?v=OQOPHVTtio0
} 


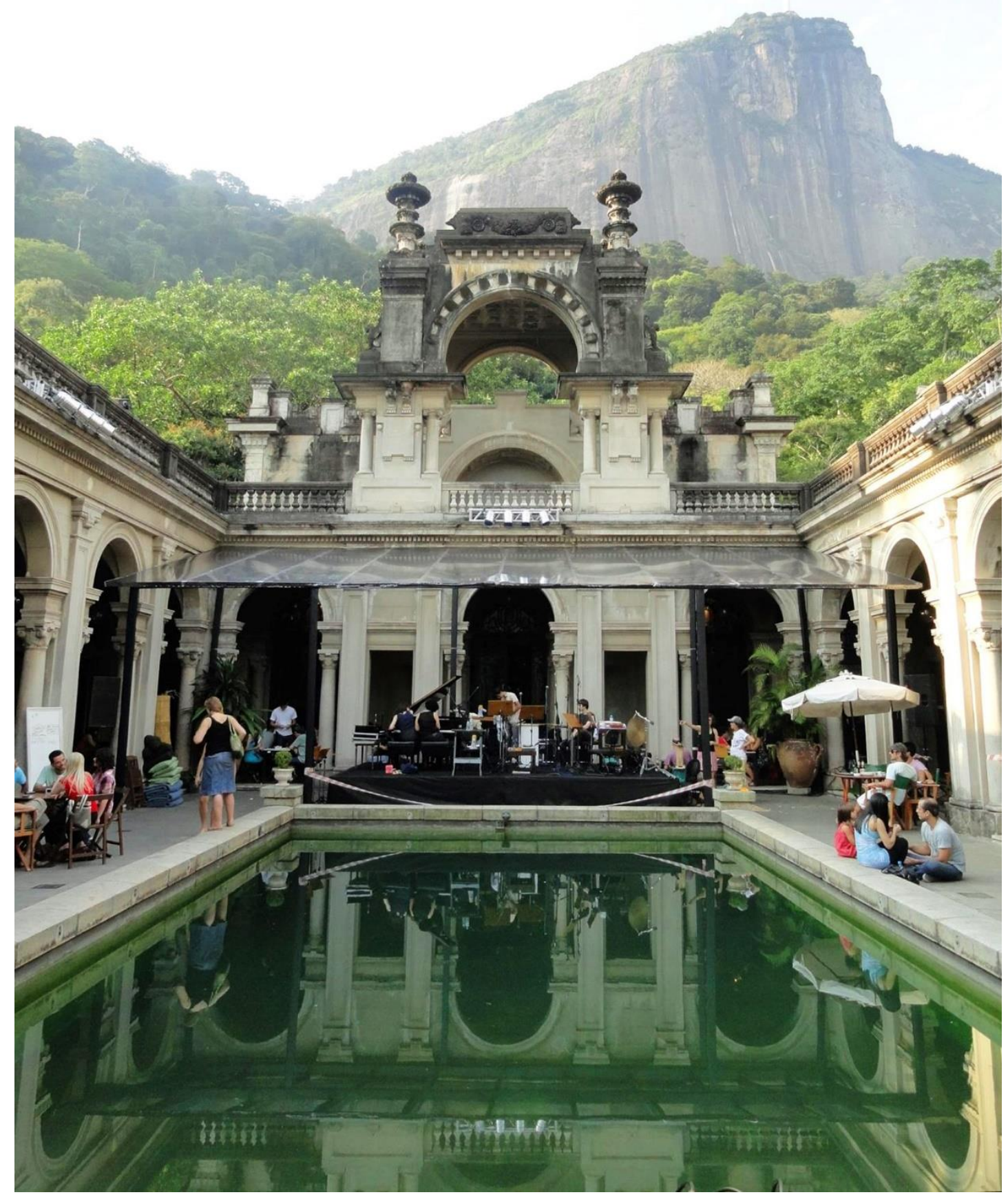

Figura 01: Imagem do ensaio para a realização da transcriação da Symphonie pour un homme seul no Parque Lage em 2010.

Uma vez estando claro que, porque nossos encontros reúnem expectativas mais ou menos diversas, o todo reflete, relativamente ao 'estrelato', uma ansiedade menor. Mesmo sendo assim preciso explicar as minhas motivações pessoais, que 
provavelmente não reverberam as de cada outro membro participante do encontro.

Recentemente fui questionado se a realização da Symphonie em 2010 ocultaria alguma agenda 'anti' qualquer coisa, se haveria ali uma proposta de crítica ou de superação estética. Respondi que não, que tinha sido pela alegria de fazer um trabalho coletivo, com pessoas queridas e sobretudo admiradas, para um público musicalmente inespecífico, porém artisticamente cultivado, o do Parque Lage. Mas para um expert no assunto a pergunta procede, porque o evento poderia conter uma intenção deliberada de mexer em vespeiro purista, pois, como já foi dito, desacusmatizamos o ícone acusmático fundamental. De minha parte, não tive essa intenção 'reacionária'.

Em primeiro lugar, porque prefiro - nada mais do que por inclinação pessoal - esse modo de escutar música no escuro. Gosto menos das músicas mistas, que me despertam de espaços multidimensionais imaginários para a tridimensão do palco, e retiram o mistério das fontes invisíveis de sons para a concreção do intérprete. 'Gosto mais' não significa 'professo a fé em', porque, em matéria de música e artes em geral, há muito tempo não aparece causa alguma justificando que eu milite a favor ou contra. E essa preferência não impede que eu me alegre por poder participar desses encontros em que, quando a tela de projeção não se encarrega da visualidade, prepondera justamente o modo 'música mista'.

Em segundo lugar porque sabia que o público no Parque Lage, embora culto, não participa da discussão dos pequenos pormenores que incham nosso meio de autoatribuída importância. É bem verdade que me encontro sem grande alento para sustentar interlocuções dentro do ambiente composicional da música contemporânea, o que atribuo ao que considero ser sua exaustão por isolamento, porque se tornou uma coletividade de 'homens sós'. A re-montagem da Symphonie foi o contrário do homme seul, só que sem qualquer ressentimento ou projeto para militância. Assim como todo o evento 'Arte Sonora'z, de minha curadoria, que a enquadrou, a revisão da Symphonie não manifesta um olhar para o passado nem para o futuro, e sim para o presente. Podemos fazer algo, agora, sem necessariamente renegarmos o passado? Creio que sim, desde que Orfeu desista de rever Eurídice. Perguntado de outro modo: é possível fazer alguma coisa a

\footnotetext{
${ }^{2}$ A apresentação da Symphonie ocorreu como parte do evento "Ciclo Arte Sonora no Parque Lage".
} 
partir do zero? Certamente que não existe zero, mas, se alguns nós forem bem desfeitos, por que não? O principal que evitamos, ali no Parque Lage em 2010, foi o nó górdio do diálogo com a expertise do nosso meio.

Tenho a impressão de ser sempre perseguido pelo mais vilão dos nós, o loop de natureza institucional. Incomoda-me a consciência de que a proteção que conseguimos construir na academia, para a manutenção da nossa atividade composicional, crescentemente nos veda de dentro para fora. Criamos um mecanismo vicioso em que uma mesma instituição produz, executa, aplaude, analisa, historiciza, comemora aniversários, escreve obituários e enterra a mesma ação, obra ou autor. Há casos em que - sem recurso às ações entre amigos, por falta deles - tudo isso, exceto o obituário e o enterro, consegue ser promovido por uma mesma pessoa. Meu problema não é tão só pela natureza eticamente duvidosa, mas pelas decorrências colaterais no plano sócio-político, especificamente pelo reforço à manutenção de um status quo. Outro loop, bem azeitado 'em nosso meio', revela-se no ecletismo das efemérides celebratórias de sua produção. Somos todos diferentes, nesse meio de experts-compositores: cada qual com sua distinta aspiração social e política. Mas, por conta do recurso ao ecletismo - por alguns, com atraso, confundido com pós-modernidade - ocorre que nos nivelamos em nosso desejo de sobrevivência. Permanece, assim, um incômodo diálogo com nosso semelhante compositor-expert.

Isso talvez esclareça por que o encontro musical, eventual e mutante, do Personne celebre uma atitude menos acomodada, mais viçosa e vigorosa, e consiga explicar o deleite de fazer parte dele.

\section{Ouvindo como 'persoa' (Jose Augusto Mannis)}

Gostaria de propor que se acrescentasse um sentido ao termo que dá nome ao grupo, o sentido de fazer soar - persoar - já que a origem do Personne se dá na proposta de transformar sonoramente a Sinfonia para um homem só, composta por Pierre Schaeffer e Pierre Henry. Estreada em 1950, na França, a obra foi originalmente concebida para gravação em disco tendo sido inteiramente realizada a partir da manipulação de sons gravados, reproduzidos e, mixados em disco. 0 uso do gravador de fita magnética, em curso de invenção naquele mesmo momento, foi operacionalizado logo em seguida, mas não antes desta composição. 
Portanto, a Sinfonia para um homem só, a SPUHS como a denominamos, até 2010, só havia sido sonificada por toca-discos, toca-fitas, CD players e outros recursos de reprodução. O grupo Personne foi o primeiro a levá-la aos ouvidos fazendo soar instrumentos, vozes e demais corpos sonoros ao vivo durante a performance. Por isso, sugiro essa acepção do título: a de um grupo que faz as coisas soarem.

A ideia insólita deste trabalho provém do artista-sonoro Rodolfo Caesar, alguém que é capaz de encontrar brechas profundas em lugares comuns, olhando por aqueles ângulos que ninguém costumeiramente olha e que, portanto, acaba vendo tudo com olhar de criança: tudo o que surge ao olhar pode ser ser (re)descoberto. Evidentemente isso desloca as coisas em relação ao status quo. E ainda mais neste caso especifico, quando tiramos algo do lugar de onde estava há mais de 60 anos! Uma música que foi criada a partir de um processo plástico de aglomeração sucessiva de sons, como uma escultura sonora, na qual os elementos estiveram gravados em sulcos de discos ou em pedaços de fita emendados e sobrepostos, seria caracterizada somente pelo seu processo de fatura, à total revelia de seu conteúdo poético? A invenção da música concreta, já em si rebelde e inovadora, transgredindo padrões anteriormente estabelecidos, teria agora, depois de concebida e estabilizada na tradição musical, de alguma forma se sacralizado a ponto de nunca mais poder ser transgredida, sem que se acuse esse ato de profanação? O proprio GRM - Groupe de Recherches Musicales, ainda na liderança de François Bayle, investiu recursos e pessoas para a concepção e realização do Acousmographe, um dispositivo desenvolvido para auxiliar a realização análises espectrais, sobre as quais é possível aplicar elementos gráficos originais que representam materiais sonoros, processos, situações e movimentos. Isso leva a uma representação abstrata dessa música registrada em mídia eletrônica, a qual se constrói a partir de uma outra representação, objetiva e neutra, obtida pela análise frequencial numérica. Segundo François Bayle em depoimento pessoal a este autor na década de 1990, o futuro da música eletroacústica estaria condicionado à possibilidade de poder observar o conteúdo destas músicas em tempo diferido e de maneira descontinua em relação a seu tempo de reprodução. Até então, as música eletroacústicas eram analisadas de memória auditiva. Compositores chegaram a elaborar partituras de escuta e estas se mostraram como um meio de poder percorrer essas músicas, comparando e confrontando momentos distintos, independentemente do tempo de sua reprodução. Por meio 
do Acousmographe buscou-se aperfeiçoar os recursos de representação aplicados às músicas eletroacústicas incorporando ao processo ferramentas auxiliares de análise do som e de colagem de elementos gráficos. Essas partituras, apesar de trazerem uma diversidade de soluções gráficas criativas e originais, mantêm sua estrutura básica geral próxima à das partituras tradicionais da música instrumental e vocal, ao menos no que diz respeito à representação do tempo no eixo horizontal e das alturas no eixo vertical. Dessa maneira, as novas soluções gráficas apresentadas são de certa forma compatíveis com a notação tradicional, podendo coabitar uma com a outra.

A transcrição da Sinfonia para a performance ao vivo realizada pelo Personne tomou o rumo da representação musical tradicional, uma vez que sua execução deveria se dar com muita precisão nos âmbitos da altura, duração, andamento e nos momentos de sincronização entre os músicos.

A transcrição ficou a cargo deste autor, tendo como colaboradores Carlos Henrique Bellaver (Londrina, PR) e Guilherme Lunhani (Campinas, SP) e logo acabou tomando o caráter de uma análise, pois as ênfases e destaques devidos à direção da atenção da escuta revelam apenas uma das interpretações possíveis da obra original (ver Fig. 02). Uma das primeiras constatações durante a transcrição dizia respeito à condução temporal dos objetos sonoros. Há andamentos claros que saltam aos ouvidos quando fixamos alguns objetos sonoros de referência. A coerência lógica evidenciada na evolução da escritura deixa crer que a mão de Pierre Henry, recém saído da classe de Messiaen, estaria empregando processos criativos adquiridos e desenvolvidos durante seus estudos, mas aqui aplicados aos processos de manipulação sonora em estúdio, notadamente às operações com toca-discos. A organização dos objetos sonoros transcritos revela traços de uma possível escritura musical tradicional subjacente às manipulações sonoras. Contudo, não se pode esperar que a transcrição tenha a pretensão de representar o que se passou pela cabeça de Henry, pois ela nada mais é do que o retrato do que os ouvidos dos transcritores interpretaram a partir da escuta da obra naqueles dias de 2010. 


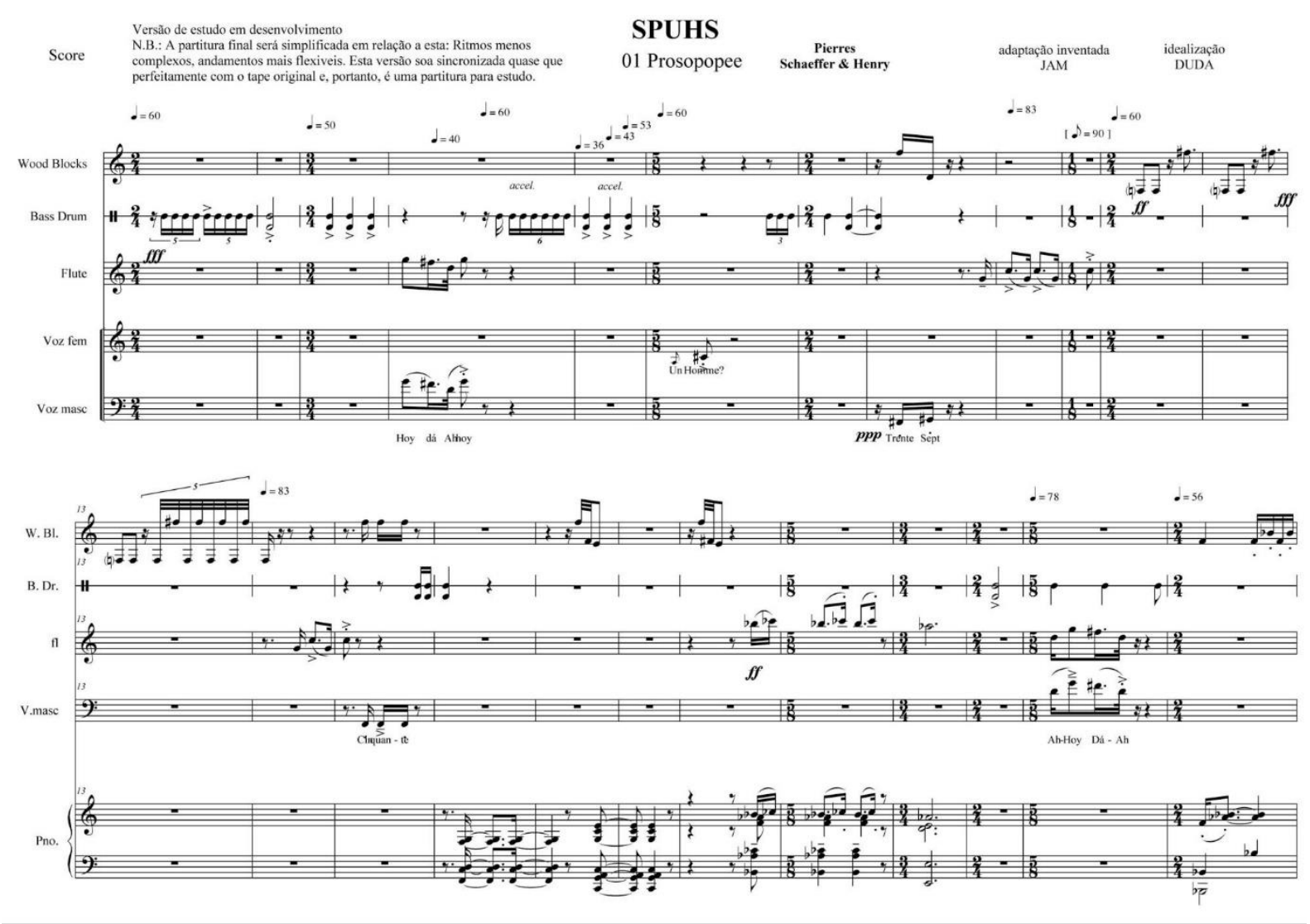

Figura 02: Transcriação instrumental do início do primeiro movimento da Symphonie, Prosopoee.

Se refeita agora, essa transcrição certamente mudaria, outros acontecimentos se aglutinariam no foco de atenção da escuta. A SPUHS poderia, sim, ser revisitada e retranscrita outras vezes, e renascida de várias maneiras. Isso decorre da concepção de transcrição, não como um gesto pretendido com equivalência e precisão absolutas de representação, mas como uma interpretação do original, para a qual as ideias, os insights e os problemas encontrados sempre foram solucionados com invenção e decisão num determinado momento. À medida em que a transcrição avançava, se aprofundava e se expandia, mais o processo tendia a uma transcriação, como quer Haroldo de Campos. E, finalmente, esta se efetivou de forma definitiva na montagem da performance da SPUHS, ocorrida em 2010, na qual cada participante compôs sua própria linha de performance pessoal, selecionando os elementos a serem tocados, cantados, ditos a partir da partitura transcrita. Ou seja, cada integrante do grupo de performance determinou sua própria parte musical combinando elementos das partes transcritas, por vezes oriundos de mais de uma das partes musicais da transcrição (ver Fig. 03). Dessa maneira, a performance realizada na sexta-feira, 15 de outubro de 2010, no 
Parque Lage, não caracterizou uma simples ressíntese direta do original, mas foi uma transcriação da SPUHS realizada a 18 mãos.
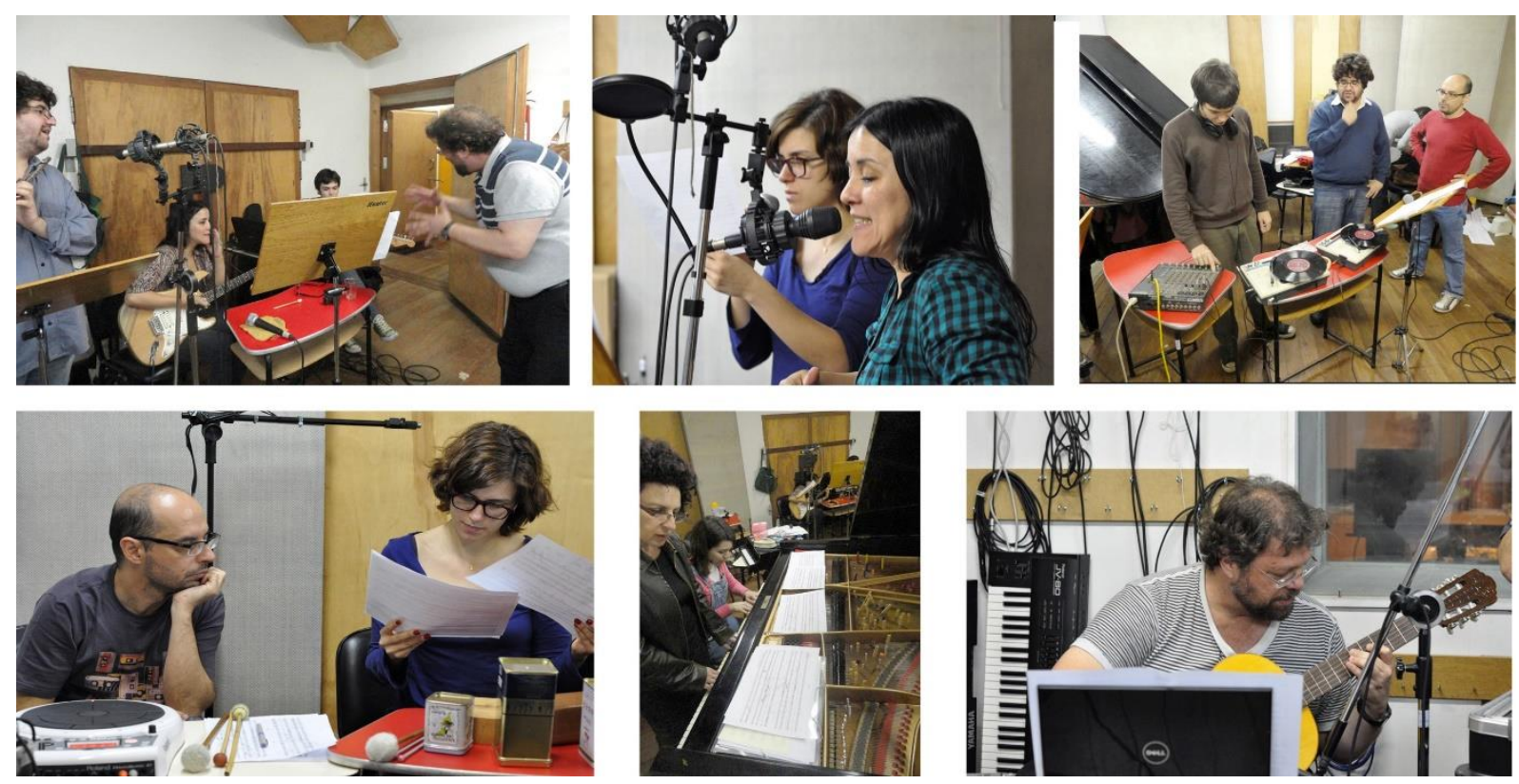

Figura 03: Ensaios de trabalho para elaboração da transcriação da Symphonie (LAMI - USP, 2010).

\section{Encontro: trocas e restos (Lílian Campesato)}

\section{Introdução}

Mais difícil do que reunir em um artigo algumas reflexões sobre as diferentes atuações do Personne, será conseguir construir uma base que dê conta de situar o leitor nesse terreno movediço. A união de modos de pensar e de escrever se apresenta aqui neste texto como uma possibilidade de compartilhar as energias que põem em movimento as ideias, sons e práticas presentes nos encontros do Personne. É claro que um texto é muito diferente de um encontro, ou de uma performance, mas talvez este conjunto de depoimentos possa ajudar a exteriorizar as preocupações, vontades e ideias de cada um de nós. Não há apenas a diversidade das propostas, há uma diversidade de atuações. As gerações e trajetórias individuais se cruzam e a maneira como se relacionam é o que dá o caráter particular deste grupo. Esses encontros entre personas guiam o desejo compartilhado de fazer e trocar. Se nossas trajetórias são distintas, nossas afinidades são o que mantém a nossa coesão. De alguma maneira eu credito à 
perplexidade com a experiência da realização acústica da Sinfonia para um homem só, a vontade do Personne de continuar criando novos trabalhos. O que aconteceu naquela noite de 2010 instaurou um desejo permanente de construir um caminho que nos levasse à manutenção de alguns ideais: troca, vivência, encontro. É sobre essas ideias que pretendo falar aqui.

\section{Experimentação: vivência}

Se existe algo em comum nos trabalhos do Personne - da realização da SPUHS às performances mais recentes - é a experimentação. Experimentar sempre foi uma espécie de meio pelo qual se desenvolveram nossas atuações. Experimentar significa testar pela ação aquilo que está ao nosso alcance. Ao meu ver, a maneira pela qual nos relacionamos com a música, sua produção e reprodução, é claramente afetada por uma dinâmica centrada na experimentação. O adjetivo experimental pode ser ingrato, pois carrega diversas atribuições, significados e até ideologias, especialmente como qualificador do termo música. Não é momento de requerer alcunhas para definir o trabalho do Personne como pertencente a esta ou aquela prática. Mas o interesse nessa conexão vem daquilo que aproxima a experimentação da experiência, da vivência. E essa vivência se dá coletivamente, numa coexistência em que se pode experimentar com o outro, compartilhar. Portanto, nossa música se dá na convivência e não na eficiência. Isso propicia abertura para as trocas entre gestos, sonoridades, atuações, porque os corpos não são rígidos, são maleáveis a interlocuções. Não há, aparentemente, uma expectativa de resolução, de atingir uma ideia ou ideal previamente almejado, mas uma vontade de trocar e, assim, deixar-se afetar pelo outro.

\section{Encontros}

Quando alguém chega frente ao outro, não importa se eles se movem em vários sentidos ou se dirigem ao mesmo ponto. O que importa é a existência do encontro e o encontro não é necessariamente uma convergência. Não haver necessidade de convergência é, ao meu ver, um dos aspectos mais interessantes de um encontro. É estar aberto ao afeto. Afetar e ser afetado, moldar e ser moldado. O resultado é incerto; não sabemos. Assumir esse risco é estar aberto a interferências e ao reconhecimento de ambiguidades essenciais.

Os encontros do Personne se deram de várias formas: conversas, ensaios, performances. O desafio inicial gerado pela realização da SPUHS foi colocado em 
vários níveis. Em primeiro lugar, a questão ética de se converter uma obra acusmática em seu oposto, numa versão instrumental e performática. Em segundo lugar, a questão poética, pois os domínios instrumental e eletroacústico, embora se cruzem com frequência, mantêm suas peculiaridades bem demarcadas. E, finalmente, uma questão musical, pois entre o projeto enquanto ideia e sua concretização no palco houve um longo e trabalhoso percurso.

O primeiro ensaio, que chamamos de ensaio teórico (ver Figs. 03 e 04), em outubro de 2010, este voltado para a apresentação da transcrição realizada por Mannis de alguns movimentos da Symphonie, e a primeira tentativa de tocá-la. Não posso esquecer da perplexidade geral que nos rondava ao encarar a dificuldade da empreitada. A partir desse encontro, todos ali souberam que a tarefa não seria interpretar com precisão aquela transcrição, mas criar a partir dela. Afinal, era a única coisa que poderíamos fazer.

Esse trabalho exigiu muito mais que criar uma atualização acústica da obra referencial da musique concrète. Os métodos e ferramentas precisaram ser inventados e testados todo o tempo, já que as dificuldades apareciam conforme cada nova mímese da obra original era realizada ou quando surgiam tensões entre as idiossincrasias da notação e a sua performance. Se a resultante desse processo se aproxima mais de uma paródia acerca da obra original ou não, é assunto para outro texto. O que importa aqui é a maneira como fomos afetados por esse processo.

Estimulados por esse encontro inicial em torno do projeto da Symphonie, outros trabalhos foram sendo gerados em diversas formações menores. O grupo voltou a se reunir com alguma regularidade nos anos seguintes, em formações diferentes. Nesses outros projetos, o Personne desenvolveu um diálogo com outras formas artísticas, especialmente com o cinema experimental, ora produzindo intervenções em filmes, criando uma trilha ao vivo, ora produzindo peças originais que extrapolam o contexto musical e incorporam outras linguagens. Algumas peças trazem à tona as tensões do cotidiano que é revisitado, às vezes com ironia, ou então de maneira crítica. 


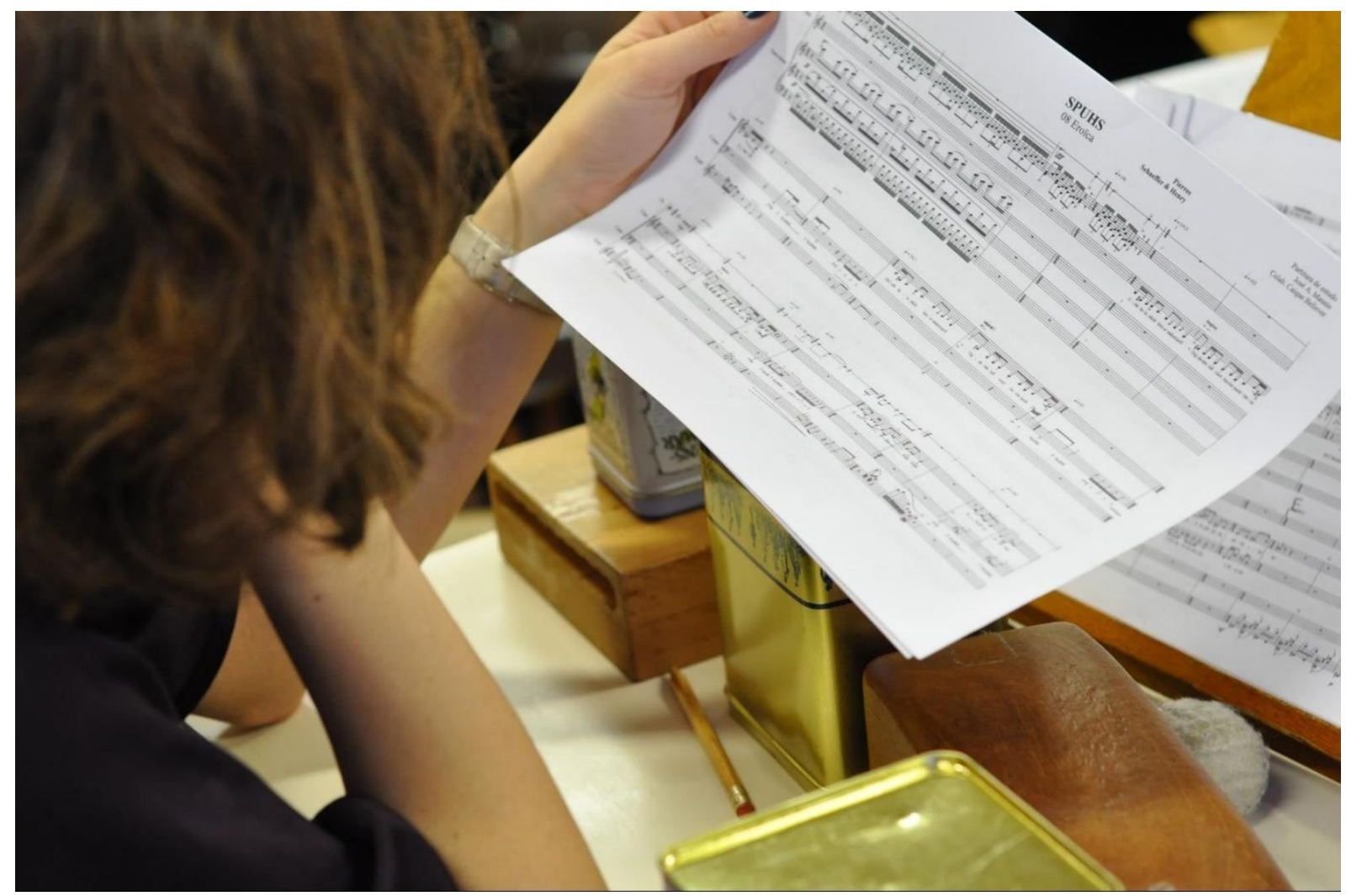

Figura 04: Partitura da performance da Symphonie.

\section{Prática}

A maioria das apresentações são pautadas pela irreverência. Elas formam uma espécie de exteriorização dos encontros, da vontade de partilhar com outras pessoas os afetos que compartilhamos dentro do próprio grupo. Ao mesmo tempo em que há um interesse na comunicação com o público, há uma ação deliberada no sentido de se evitar que os trabalhos adquiram um caráter hermético ou que retenham traços acentuados de um academicismo. Ao contrário, buscamos uma proximidade com o público que é facilitada pelas narrativas e referências que fazem parte dos materiais que utilizamos. 


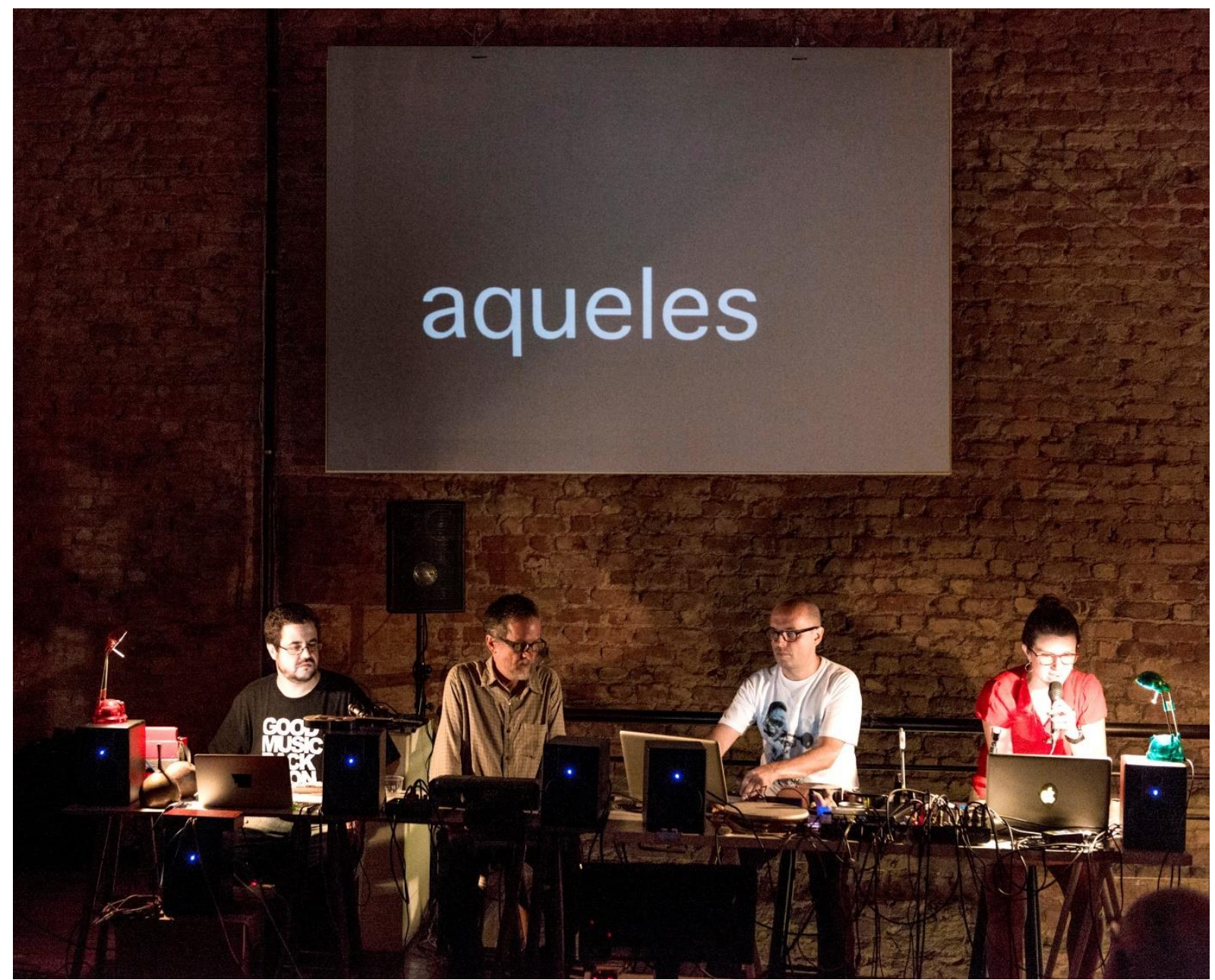

Figura 05: Apresentação da performance baseada no filme Dreams That Money Can Buy (1947), de Hans Richter, no Parque Lage, Rio de Janeiro.

Os trabalhos realizados depois da experiência inicial com a Symphonie criaram uma forte relação com materiais imagéticos, principalmente vindos do cinema. Neste sentido, a música passou a dividir seu território com a imagem e os sons passaram a ser afetados por elas. De alguma maneira, os filmes se transformaram em mote para a construção das performances, e o processo de tomar as imagens como elemento de partida pode ser visto como uma espécie de método adotado pelo Personne desde então.

Gradualmente nos tornamos músicos de cinema, como nos primórdios do cinema mudo, tentando transformar em som o que assistíamos na tela. Em filmes como Dreams That Money Can Buy (1947) ou Ghosts Before Breakfeast (1928), ambos de Hans Richter (ver Fig. 05), os estados de espírito, o clima ou o pathos das cenas foram traduzidos livremente por gestos musicais. "Livremente" tem um sentido 
particular aqui: não se segue uma cartilha sonora pertencente a este ou aquele estilo - nem mesmo ao que se refere ao modelo "improvisação livre" típico de certas práticas contemporâneas. Cada membro do grupo traz seu aporte muito pessoal a algo que poderíamos denominar uma improvisação guiada pelos afetos emanados dos filmes, os quais atingem cada músico diferentemente.

Os materiais sonoros podem ser os mais diversos. Às vezes são resultados por um objeto curioso (uma peça de decoração, um aparelho quebrado, um pedaço de sucata) trazido por um dos músicos, objet trouvé cuidadosamente transformado em instrumento. Outras vezes podem ser mesmo peças musicais previamente compostas por um membro do grupo, que as oferece para que os outros toquem "sobre" elas, formulando um ciclo em que obras se transformam novamente em material sonoro para gerar uma nova música. Esses materiais pré-compostos não funcionam como um convite à interação, mas sim à esculhambação (esculhambar + ação).

Sambado faz parte de uma das quatro Peças para 'lounge' (2005) de Rodolfo Caesar que usamos como fundo e mote para a esculhambação. Lembro que foi sugestão do próprio Rodolfo usarmos uma dessas peças compostas em outros contextos. O que fizemos foi farrear com a peça, tocando sem uma preocupação implícita em respeitar a dinâmica formal ou a textura, mas com o cuidado de atentarmos à tensão com que a nossa atuação se apresentava.

Porém, se o método é descompromissado, o trabalho não. O que guia as performances são a atenção e a escuta coletiva. O aparente descontrole é na verdade guiado por uma tensão constante, um esforço para manter a abertura de possibilidades: o controle para que se dê espaço ao descontrole. O tempo todo, a performance se coloca como uma provocação. Às vezes aparecem, imprevisivelmente, alguns daqueles sons malditos, indesejáveis, estranhos. Mais uma vez, eles adicionam tensão à prática. Reclamam uma articulação ou mesmo um desvio.

A produção desses sons também não obedece uma lógica de performance instrumental. Alçamos à categoria de instrumento tudo aquilo que podemos mobilizar para produzir sons. Assim, os "instrumentos" são diferentes em sua natureza e não se complementam em nenhum sentido musical tradicional. Por exemplo: não há um instrumento grave complementando outro agudo, ou um "melódico" complementando outro "rítmico" ou "harmônico". Cada um dos 
membros do grupo possui um set-up diferente e heterogêneo. Por exemplo, Rodolfo Caesar trabalha com um sampler acionado por pads de bateria eletrônica, no qual tem armazenado sons pré-gravados postos em loop. O controle da velocidade de cada sample usado por Caesar impõe um ritmo próprio. Transborda o simples diálogo entre os participantes, já que os samples disparados conduzem a uma interação num ritmo particular.

Já a microfonação da minha voz é o que tomo como fonte principal de atuação. O uso de dispositivos eletrônicos, como ring modulator, granuladores, flangers ou delays, altera a relação entre voz direta e voz processada. Ao mesmo tempo, quase como extensão das pregas vocais, são acionados diversos instrumentos metálicos de percussão. De forma semelhante, Alexandre Fenerich toca uma série de pequenos objetos, muitos adquiridos em uma feira de antiguidades: apitos, um cálice de metal usado como sino, um pé de boneca de louça, caixinhas de música, flautas de brinquedo. Seus sons também são processados, colocados em loop, granulados. Em uma das performances, Fenerich toca um afoxé quase no mesmo andamento de instrumento percussivo que aparece numa trilha pré-gravada. "Quase" significa aqui o embate entre o erro e o despropósito. O afoxé tocado "ao vivo" é a representação mal constituída da percussão gravada. É um contraponto, não um acompanhamento: é a representação da memória do gesto da percussão gravada. O que ele faz ao vivo se transforma, neste caso, em representação do gravado.

\section{Resto, troca e escambo}

Em algumas práticas musicais do Personne, permutamos entre nós os materiais criados por cada um, desconsiderando qualquer valor musical intrínseco e abrindo mão da autoria individual de cada material criado. A obra - se é que há alguma nasce desse encontro entre os músicos e do seu trabalho com os materiais partilhados.

As afinidades pessoais certamente acrescentam muitos outros elementos que são trocados, para além dos materiais sonoros. Por exemplo, durante uma das cenas da performance baseada no filme Dreams that money can buy, os músicos imitavam a ação dos atores que levavam a mão defronte da testa e indicavam, com a inclinação do corpo, que observavam algo numa direção específica (ver Fig. 06). Ao "reproduzir" a cena do filme - subir na cadeira tal como os atores -, imitar 
seus gestos e se afastar por um momento da criação sonora, faz-se uma conexão de outra ordem entre os atuantes, o filme e o público.
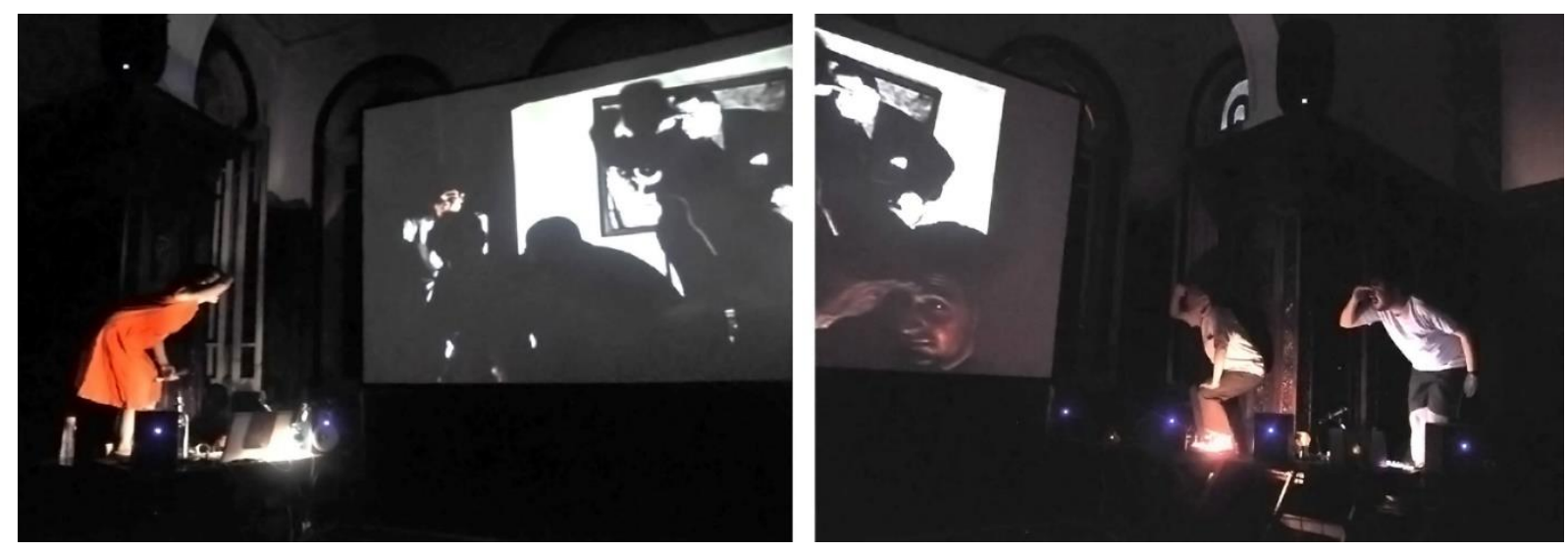

Figura 06: Cena da performance Dreams that money can buy em que os músicos imitam em cena os gestos dos atores do filme.

Essas trocas, não apenas materiais, adicionam camadas de interação e podem deixar vestígios, especialmente daquilo que sobra em qualquer troca. São remanescentes dos encontros, produto das trocas, essas diferenças que aparecem sempre. No encontro entre um gesto ou uma proposição sonora criada por um músico e trabalhada por outro, surge um resultante, que tem em si a memória dos dois. A diferença desse novo material em relação aos originais seria o resto? Parece que sim.

Em toda troca há um resto decorrente da diferença entre seus valores de troca. Não que a diferença seja o reforço de valores, pois não me parece que nos importemos com isso, mas ela é o mote que é utilizado por nós como um desafio poético. Talvez seja justamente a existência desse resto, essa diferença, o dispositivo fundamental de produção de mudança e articulação entre as proposições individuais, os materiais fílmicos ou a interação de um com o outro. Mais uma vez reforço que não há necessidade de uma convergência, pois são justamente as diferenças que tornam o encontro tão interessante. 


\section{Celebração e Jogo: performance musical enquanto troca de imagens sonoras (Alexandre Fenerich)}

\section{Falsa musicologia}

Escrever sobre o próprio trabalho criativo é, na maior parte dos casos, uma atividade ingrata ou desonesta. Incorre em distorções inevitáveis de uma voz narrativa neutra, a qual esconde, pelo artifício da objetividade, posições parciais que tendem ao elogio de si mesma - voz em terceira pessoa que descreve e analisa um objeto cuja isenção jamais encontrará.

Apesar disso, como que sobre o fio de uma navalha, este texto pretende discutir posições éticas e estéticas do grupo Personne no contexto em que suas performances mais recentes se inserem. Busco pensá-las enquanto dispositivo musical ao sintetizar alguns dos procedimentos recorrentes em sua dinâmica de criação.

Embora haja outras formações do grupo e outras abordagens musicais, aqui gostaria de discutir os trabalhos cuja constante foi a criação a partir de e com imagens fílmicas - atuando sobre trechos de filmes e recriando-os pela intervenção cênica e sonora. Pois muito do que o Personne tem feito não é estritamente música do modo como este campo se identifica, mas sonoplastia ao vivo. Isso não é nenhum demérito: a reação aos impulsos, imagens e ambientes sugeridos pelos filmes com os quais trabalhamos é um gesto de criação sonora tanto para nós, intérpretes/compositores - para quem o ato de recriação em resposta às imagens visuais é um jogo prazeroso - quanto para quem nos assiste, que se deleita com a nossa (in)habilidade de representação e de pronta resposta.

Recorro muito a Jacques Tati para fazer, pensar e me divertir com música e cinema. Seus filmes são criações musicais precisas, leves, cheias de matizes. 0 trabalho de foley em Playtime (1967), por exemplo, traz algo de intangível na contraposição entre a fotografia opaca e os sons claríssimos - ou algo de cômico e onírico na caracterização sonora e rítmica de alguns personagens. A precisão milimétrica da colagem temporal dos sons nas imagens, por um lado e, por outro, o descompasso entre as dimensões dos objetos vistos na tela com seu correspondente visto-escutado pelo gesto sonoro ao vivo, são talvez aspectos técnicos da recriação fílmica do grupo, com influências de Tati. 
No entanto, não são estes elementos que gostaria de marcar aqui. Prefiro, ao invés, pontuar as posturas estéticas e éticas do Personne nestas práticas de recriação fílmica que me parecem significativas. A motivação criativa do grupo é peculiar no contexto musical atual, e merece discussão. Começo, pois, o texto comentando o principal motor de sua iniciativa - um encontro entre amigos discutindo as implicações que esta tem para o próprio trabalho e em sua inserção nos circuitos musicais brasileiros de classe média - como entendo ser os ligados à música de concertos, aos quais, pela formação e inserção de seus membros, o Personne se incluiria.

\section{Celebração, jogo}

O elemento mais forte dos trabalhos mais recentes do grupo Personne não se relaciona a um caráter de obra de arte autônoma, que basta a si mesma enquanto objeto a ser apreendido. Não é na escuta isolada das performances que se retém seu caráter ao mesmo tempo rigoroso e flutuante e, sobretudo para os espectadores e músicos, leve. Uma escuta superficial de suas apresentações poderia indicar que os músicos não possuem compromisso algum com o material musical, que não são sérios, que uma certa confusão sonora é resultado de sua inabilidade. Ao mesmo tempo, que não trazem a tensão que caracteriza uma performance musical tradicional, ligada a um respeito à tradição ou a um autor que a aproxima de um culto religioso. Com valores ligados à espontaneidade, as performances são, sobretudo, a afirmação de uma ética, ligando-se a um sentido de celebração do encontro entre amigos. Pois o grupo é composto por pessoas cujo vínculo de amizade prevalece sobre os demais e que residem em lugares distantes entre si, sendo a preparação de cada espetáculo pretexto para sua reunião. Elas possuem, assim, no prazer do encontro, sua mais forte motivação, e o espetáculo que se mostra é a consumação deste ritual: a construção de um diálogo ao redor de um eixo comum - um filme e sua narrativa.

Celebrações que são, porém, de outra ordem com relação às reuniões convencionais entre amigos: são regidas pelo som e, portanto, não estritamente verbais - ou seja, não regulamentadas unicamente pela linguagem verbal. Eu diria que nas performances operam-se interpretações de cada músico das imagens fílmicas, traduzidas em imagens sonoras, as quais são postas na mesa em diálogo não verbal, permitindo trocas de imagens sonoras. E com objetos com maior abertura semântica, estas trocas se efetuam em outro nível e complexidade: 
podem ocorrer na simultaneidade, e não apenas cronologicamente. E estão para aquém (ou além) do conceito, constituindo imagens semanticamente densas, ou seja, em que mínimas nuanças são significantes. Operam portanto num registro mais sutil e menos preciso que em diálogos estritamente verbais, sendo mais voláteis e propensas à maior densidade de eventos, por se sobreporem e se retroalimentarem umas às outras em nuanças mínimas.

$\mathrm{Na}$ permuta desses objetos desviados das imagens fílmicas tem-se um jogo em que se decantam duas camadas: uma é a construção das trocas entre imagens sonoras; a outra é a imersão do grupo na escuta deste diálogo, na tentativa de moldar a sonoridade geral a partir de um gesto sonoro individual, o qual será escutado e assimilado pelos demais. Processo em redemoinho pela intensidade temporal, em que, no caso das recriações fílmicas, ao mesmo tempo se olhaescuta o filme original, se atua, e se escuta os demais, a fim de moldar o resultado. Atividade de extrema concentração mas, ao mesmo tempo, de liberdade, pois não há resultado fixo a ser alcançado.

Eis o jogo: qual o melhor instrumento para sonorizar certa cena, e deste, qual dos seus sons a ilustra? Qual gesto? Escolho-os, mas meus companheiros selecionam outros instrumentos e outros sons. Colocamo-nos em escuta, dosamos nossos gestos, silenciamos ou tocamos. Jogo de encaixe, por exemplo, entre um som de uma caixinha de música e a imagem de um bandido galã: junção entre estas imagens que formam, pela colisão, uma terceira. Mas a amálgama é quebrada instantaneamente por uma outra solução, dada ao mesmo tempo por um segundo integrante do grupo, que acopla outro som com aquela imagem visual. Digamos que ele toque sobre a caixinha de música um acordeom, e um quarto sentido se forma. E assim sucessivamente: "jogo aberto, isto é, que modifica suas próprias regras em todo lance" (Flusser, 2008, p. 129). Mas jogo descompromissado com resultados fixos ou ideais, que se dá na construção incessante de sentidos - por vezes no limite da entropia - através de um diálogo entre imagens de sons. Estas, por sua vez, são significadas e significam incessantemente os contextos fílmicos explicitados na tela. "Movimento enquanto movimento, que quer dizer um fenômeno de redundância, de auto-representação do estar vivo" (Gadamer, 1985, p. 38) - mas movimentos regrados pelos contextos aos quais os diálogos se sobrepõem. 
Se nas performances prevalece como força motriz uma dinâmica no limite do entrópico, não se perde, todavia, a liberdade individual nunca cerceada por qualquer membro do grupo, na escolha das sonoridades e dos objetos, além do modo de os tocar. As palavras de Flusser sobre o jogo e seu ato parecem adequarse perfeitamente à prática do grupo: "os músicos se perdem uns nos outros", sendo "simultaneamente emissores e receptores, individual e coletivamente, da mensagem que elaboram (Flusser, 2008, p. 195). Temos, portanto, a afirmação de uma prática não inserida em um pragmatismo qualquer - de um fim para além do simples prazer de jogar. Afirmação de um jogo que é um diálogo sonoro em que os participantes partilham entre si e com os ouvintes certa lógica - a relação com um filme - sem, contudo, construírem nada de necessariamente fixo - com o que perderiam a natureza fluida do diálogo, que caracteriza a sua atividade.

Mesmo os seus ensaios ilustram o caráter informal próprio de um grupo de amigos mas, ao mesmo tempo, ritual de sua prática musical dialógica. Neles pouco há de convencional ou pragmático, no sentido da preparação para uma realização bem sucedida da performance a ser realizada. Há, evidentemente, a configuração de uma infraestrutura a partir da qual iremos atuar: a seleção dos filmes e seus trechos, além da preparação das matrizes a serem tocadas. A preparação dos sets ${ }^{3}$ individuais, sempre montados para uma peça específica; finalmente, a escolha de gestos e sonoridades que podem ficar entre as performances, consensualmente encontrados pelos insights coletivos ou individuais.

Mas mesmo a elaboração do set é um evento regrado pelo prazer do encontro, a partir, por exemplo, de trocas de objetos materiais ou imateriais (instrumentos, "sons" ou "patchs"4) ou de rituais de busca. Lembro-me que durante a preparação de um dos concertos eu, Liliza Mendes e Lilian Campesato fomos à caça de cacarecos sonoros no mercado de pulgas da Praça XV, no Rio de Janeiro. A busca foi feita após termos assistido a Dreams that Money Can Buy - filme sobre o qual trabalharíamos - e estávamos imbuídos do seu tom surrealista. Alguns dos objetos que encontramos fizeram parte das performances, e por isso tiveram um fim pragmático.

\footnotetext{
${ }^{3}$ Isto é, do conjunto de instrumentos materiais ou imateriais com os quais cada pessoa irá trabalhar.

4 Por "sons" quero dizer arquivos de som. Patchs são como são chamados arquivos de texto que armazenam estruturas de programação de softwares voltados para a criação musical, como o Max/MSP, Pure Data ou Open Music.
} 


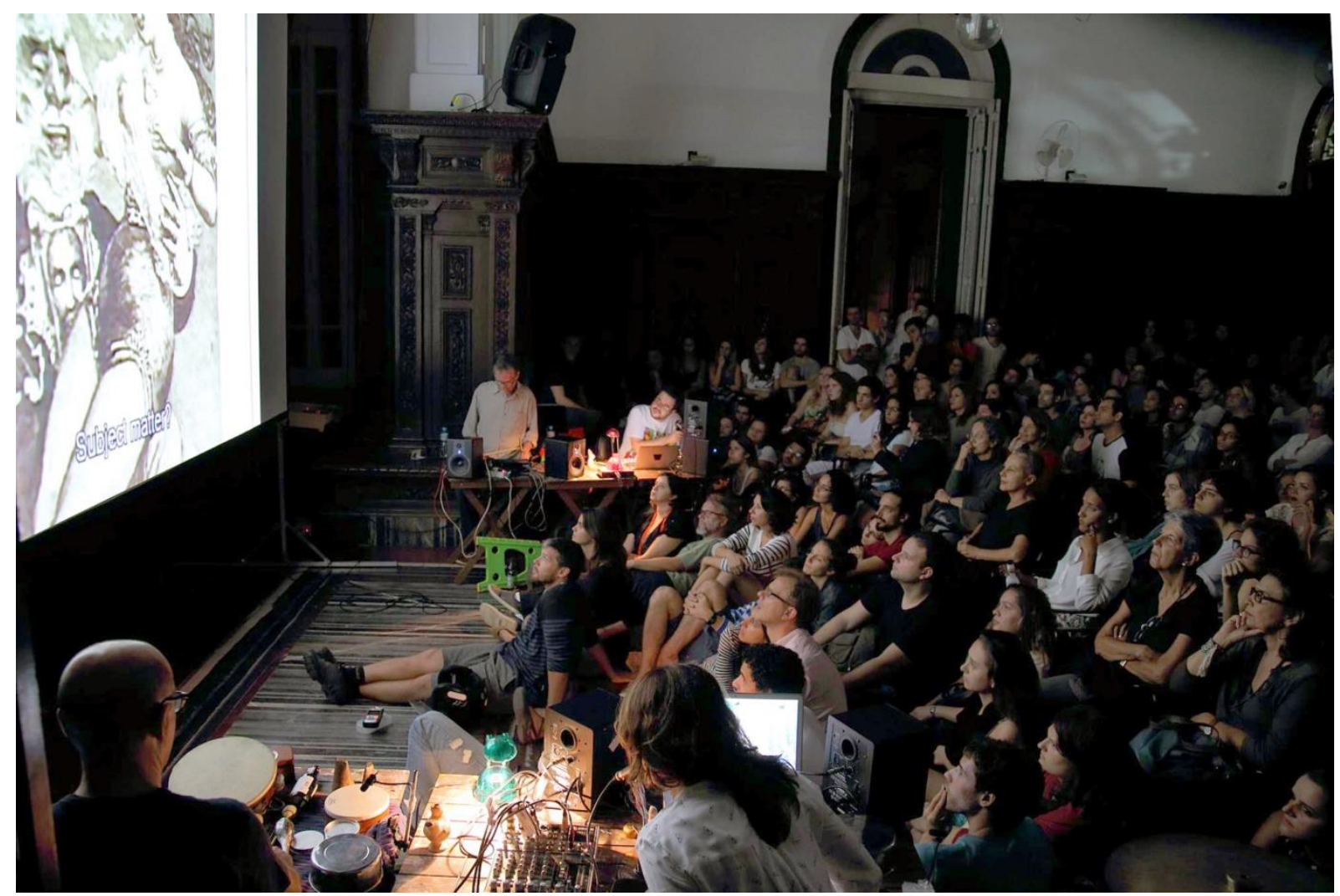

Figura 07: Apresentação do Personne em abril de 2014, durante o evento Encontros Carbônicos no Largo das Artes, Rio de Janeiro.

Mas suas escolhas, pelo absurdo que portavam enquanto instrumentos musicais, foram deleite coletivo no sentido de criar possíveis usos. Foram eles uma velha maraca cubana, um cálice de missa quebrado que serviu enquanto sino, instrumentos de dentista usados como baquetas irritantes, um pé de boneca de porcelana - igualmente baqueta cretina - sinetas de telefones antigos, latas velhas e charmosas de biscoitos ou chás usadas enquanto instrumento de percussão, dentre outros. Estes objetos compunham, ao mesmo tempo, instrumentos musicais ou de sonoplastia e elementos de cena, em contraponto com as imagens vistas/escutadas na tela. Sua procura no mercado de pulgas fora marcada pelo olhar ao acaso entre as inúmeras peças que exibia - um passeio como que a uma exposição, feito pelo trio, que os selecionou na medida em que ofereciam ressonância visual ou sonora com o que desejávamos.

\section{Profissionalismo}

Outro aspecto correlato aos discutidos anteriormente é o da natureza do trabalho do grupo com relação ao seu status de obra musical e de atividade musical 
profissional. Suas apresentações mais recentes não foram profissionais por não terem sido remuneradas como seriam no mercado musical. Foram obviamente remuneradas, mas a valores aquém do mercado. Com isso, fala-se muito da sociedade na qual nos inserimos - já que o grupo tocou em eventos promovidos por escolas de arte, ou organizados por coletivos de arte e em universidades - ou seja, por instituições que, em tese, deveriam remunerar propriamente os artistas que nelas atuam. Mas ao aceitar estas condições de performance, o grupo afirmou um certo sacrifício em favor da manutenção do ritual de encontro - de uma vontade de realização cuja expectativa é muito mais pelo prazer de mantê-lo que pela retribuição por um trabalho realizado. Este texto, aliás, vem a enfatizar este caráter, embora eu tema que possa se tornar objeto de aferição acadêmica, e, portanto, em contradição com o espírito do encontro.

$E$, no entanto, creio que não foi por acaso que as apresentações se deram em espaços institucionais ligados às artes visuais e ao cinema: parece-me que nesses ambientes a comunidade é mais receptiva a práticas de performance não normatizadas enquanto "musicais" - pouco aceitas nos espaços ligados à música de concerto ou mesmo aos lugares institucionalizados da música popular. Estas são opiniões colhidas de minha experiência ao atuar em ambas as àreas, ocupando os espaços da música institucionalizada e aqueles destinados às artes visuais ou ao cinema, mas que foram receptivos em relação a propostas como as deste grupo. Aprendi daí que nas instituições musicais, uma proposta como a do Personne teria pouca ressonância. Seu caráter aberto, distante do conceito de obra no sentido ocidental, não se adequa totlamente ao que se espera tradicionalmente de uma performance musical.

Mas desconfio que o seu aspecto irreverente - decorrente de uma despretensão face à realização de uma obra musical, além de não pretender se vincular a correntes da música de concerto ou popular - é aquilo que menos se enquadra nos meios musicais destinados ou realizados pela classe média brasileira (que são, afinal, o público e os realizadores de Personne). Uma classe social que tradicionalmente se liga a valores como a vinculação estilística e histórica, o rigor técnico, a aparência de dedicação e trabalho, o especialismo e/ou eruditismo, a autoria e o acabamento formal - os quais, tomados em si mesmos, não se articulam com um contexto mais amplo da sociedade brasileira (Flusser, 1998, p. 53, 79; Cocco, 2014, p. 114). São valores que esta classe construiu para si a fim 
de separar-se tanto das classes baixas, pela exaltação da erudição e do especialismo conquistado pela dedicação temporal, quanto das altas, pela valorização do trabalho enquanto esforço individual.

Não que não partilhe, mesmo inadvertidamente, algum desses valores. Mas o grupo não se compromete com eles. Isso se reflete em performances descontroladas do ponto de vista técnico, irrepetíveis, cômicas, não vinculadas a estilos musicais específicos, e não autorais no sentido de não serem reguladas por uma hierarquia do tipo compositor/intérpretes, ao não contarem com uma direção ou regência.

\section{Dispositivo Musical}

Neste texto tive a intenção de discutir como nas últimas performances do grupo Personne privilegiou-se a troca de sonoridades produzidas ou "achadas" em torno de um tema fílmico, ao invés de um certo resultado sonoro fixo. Com isso o que é enfatizado na atividade do grupo é a natureza da atividade, e não uma obra ou objeto a se fixar pela memória. O que fica para seus membros e o público é um jogo vertiginoso de imagens sonoras relacionadas a objetos extrínsecos aos criados ali (os filmes). Suas performances são um fazer que privilegia o imaterial sobre o material, sendo mais um dispositivo de criação que um objeto: não são obras, visto que não é possível apreendê-las estaticamente. O dispositivo é pretexto para o encontro e consiste na troca entre imagens sonoras inspiradas por imagens visuais, narrativas, contextuais ou gestuais. E todo o ritual de preparação das performances é um fato estético, por trazer elementos a esse encontro entre amigos que não estariam presentes em uma reunião normal: a moeda de troca a partir do som e das imagens fílmicas, além do jogo de escolha dos elementos postos na mesa. Por fim, o fato de não se situar no espaço do profissionalismo musical faz com que as apresentações do grupo e sua preparação contenham o caráter de ritual de celebração da amizade pela música. Enquanto pretexto para o encontro, a atividade musical que daí decorre ganha um outro contorno, marcado pela ética da amizade, na qual a liberdade - e não a repetição, a correção ou a busca por um ideal, enquanto beleza extrínseca ao próprio ato - é o maior valor. O próprio caráter não virtuosístico dos músicos reafirma a ideia de que os ouvintes também poderiam fazer o que eles realizam em cena, atenuando sua separação intrínseca. 
Gostaria de enfatizar, assim, o aspecto de dispositivo musical que traz consigo uma ética e um procedimento, os quais diferem das práticas musicais usuais e trazem os valores e as características que marcamos aqui. Dispositivo no sentido que coloca Benjamin em "O autor como produtor" - ou seja, de procedimento de criação de novos procedimentos de criação, ao invés de produtos. No dispositivo de Personne valoriza-se um jogo que reformula suas regras no próprio ato de jogar, emergindo daí escutas e gestos de imagens fílmicas em diálogo, cujo resultado tende a ser volátil e inapreensível. E se há alguma mensagem que resta desse fazer, é a significação do próprio jogo - a de um diálogo sonoro em espiral, cuja imagem da liberdade entre seus jogadores e da alegria do encontro é a mais forte celebração da amizade dentre os vários aspectos do dispositivo proposto.

\section{Tocar sem compromisso (Fernando Iazzetta)}

Certa vez, um colega compositor disse que a função da arte era propor boas perguntas. Como todo aforismo, a colocação pode revelar verdades profundas ou banalidades superficiais: tudo depende do como usamos a frase. Se (felizmente) não é possível tomar o aforismo como regra, tenho que reconhecer que ele é revelador de uma certa atitude em relação à criação musical que me parece interessante. Vejamos: fazer música pressupõe uma série de contextos e condições que, se não definem a música, estabelecem seus contornos, ainda que de maneira difusa. Sala de concerto, palco/plateia, partitura, quarteto de cordas, vanguarda, serialismo não são apenas expressões que rementem a questões musicais, mas são também construções simbólicas, sociais e culturais que compõem esse cenário. Se não é possível pensar a música totalmente fora desse tipo de questão, qualquer conjunto de termos como esses será sempre insuficiente para demarcar o que é a música.

Tomo por exemplo o termo música contemporânea, que se presta a designar um tanto de coisas criadas em nome da música nos últimos 100 anos. O termo revela no mínimo a atitude preguiçosa de quem prefere não confrontar tantas visões diferentes para onde convergem as músicas do período. Essas músicas contemporâneas dependem de um sentido de comunidade para existir, e cada comunidade - serialistas, roqueiros, acusmáticos, neo-românticos - se esforça por constituir um espaço tão particular, quanto delimitado para criar e difundir sua 
arte. Mas genérico e generalista, o termo música contemporânea se aproveita do fato de dizer pouco para servir de emblema usado por todo mundo que aspira dizer alguma coisa com música. Se ainda há algo para se extrair da ideia de música contemporânea, talvez seja a compreensão de como essas comunidades se articulam, competem, espelham-se e distinguem-se.

Quando escolas, estilos e técnicas estão mais ou menos bem colocados, o trabalho da composição é fazer-se reconhecer dentro deste repertório. Compor passa a ser uma busca de diálogo com algo que já se encontra desenhado (serialismo, espectralismo, nova complexidade, minimalismo). Se, por um lado, temos um terreno fértil para a criação artística, por outro, surge um curto-circuito, quase autofágico, daqueles que fazem música alimentando-se da busca pelas próprias soluções musicais. Quando não se pode sair desse círculo, em que se buscam novas respostas para as mesmas perguntas, corremos o risco de acreditar demais nas soluções que encontramos e pensar menos em por quê fazemos música, ou por quê alguém estaria interessado na nossa música.

Não é fácil, e para muitos, nem necessário, livrar-se disso. Mas há outras saídas para as inquietações que movem aquilo que chamamos de música. Voltando ao aforismo inicial, podemos, por exemplo, inventar novas perguntas ao invés de nos sentirmos responsáveis por encontrar boas respostas. Uma boa pergunta é antes de tudo uma oportunidade de compartilhar algo - uma boa resposta talvez seja apenas um momento de encerrar uma discussão -, de estar não apenas aberto àquilo que ainda não está consolidado, mas também à vulnerabilidade e à instabilidade de não se saber onde as coisas vão dar.

O que se chama experimentalismo em arte traz um pouco desse espírito. Ainda que o termo seja tão impreciso quanto difuso, ele está geralmente associado a uma atitude de ruptura em relação ao círculo das questões já colocadas. O experimentalismo seria uma espécie de aventura num terreno que ainda não está formado. Não há nada de devaneio nisso, apenas a possibilidade de um passeio por onde ainda não se vê com clareza um caminho.

Considero que, em alguma medida, um grupo como o Personne proponha algo assim. A não responsabilidade por apresentar as respostas certas e um 'despertencimento' a qualquer comunidade já consolidada abre espaço para que se (re)apresentem coisas que há muito foram separadas da música contemporânea "séria". Uma dessas coisas é justamente a diversão. Não 
exatamente a falta de seriedade, mas o descompromisso de atender às normas e aos bons costumes. É claro que eles existem, e estão possivelmente impregnados na formação de cada um dos músicos do grupo. Não é à toa que em diferentes línguas o termo música aparece conectado a adjetivos como "erudita", "savant" ou "serious" para indicar uma prática circunspecta e contida. É possível ser divertido sem perder a seriedade, já que existe uma ética que está por baixo dos trabalhos do Personne. Essa ética guia a estética, que, por sua vez, é dominada por uma postura que privilegia os desejos e as intuições e não a lei e a ordem da música. Antes de tudo, os processos são movidos pelo que é coletivo, ainda que as ações e decisões não sejam consensuais. Chamo isso de generosidade.

A generosidade abre caminho para esse aspecto que domina o trabalho do grupo: a criação coletiva. Não se trata simplesmente de romper com a condição de criador e criatura, compositor e obra, mas especialmente de gerar estratégias de entendimento mútuo. Atuar coletivamente não significa apenas dividir tarefas de composição, mas antes ser cúmplice daquilo que é feito pelo outro. Torna-se necessária uma relação de confiança entre os membros, permitindo que se assumam riscos, os quais são compartilhados por todos. Por isso, nas performances não há erro. Existe apenas uma tensão saudável trazida pelo processo de transformar o inesperado em música. Essa é uma distinção em relação às práticas musicais baseadas na escrita e num pensamento individual que se dão num tempo estendido e diferente daquele da performance. A escrita assegura a existência de um processo de composição regulado, assegura a permanência das ideias e assegura, antes de tudo, a instauração de um pensamento estrutural e estruturalizante da música.

Ao se abdicar do processo de composição, surge um outro tipo de problema: como dar corpo a algo que, aparentemente, não parte de uma forma preconcebida? 0 primeiro desejo é recorrer à ideia de improvisação, espécie de termo-guardachuva, em que o tempo de compor está colado ao tempo de tocar. Mas a palavra improvisação, sozinha, diz pouco sobre as múltiplas possibilidades de expressão musical que se instauram fora do âmbito da composição. Em muitos casos, a improvisação se sustenta pela prospecção dos eventos sonoros que vão ser gerados nos próximos instantes em sua relação com um passado muito próximo. Assim, a performance improvisada pode construir-se numa espécie de janela temporal, muito estreita e deslizante, na qual os músicos buscam criar relações 
entre aquilo que acabou de ser tocado e aquilo que será imediatamente produzido em termos de som. Esse espírito altamente focado no presente e o aspecto interativo de ação e reação imediata entre os músicos é o que guia, por exemplo, boa parte do que chamamos de improvisação livre. Mas no Personne, essa relação é, muitas vezes, posta de lado. O que está sendo produzido por um músico não precisa estar relacionado dessa maneira pontual e necessária com o que os outros músicos estão tocando. Ao invés do aspecto de dualidade que sustenta muitas vezes as práticas improvisativas - pergunta e resposta, ações contrastantes, relações entre cortes e continuidades -, provocamos uma instabilidade pela superposição de elementos musicais que podem ser bastante desconexos. Se não há necessariamente uma situação de pergunta e resposta, surge possibilidade para a incorporação daquilo que é meramente acidental. É claro que há um jogo entre o controle e o descontrole, mas forçar a possibilidade de criar algo musicalmente interessante a partir do choque não intencional de figuras sonoras diferentes cria uma tensão saudável entre os músicos, um estado de atenção permanente, já que a qualquer momento pode-se abrir uma brecha nos sons, em que alguém pode intervir durante a performance.

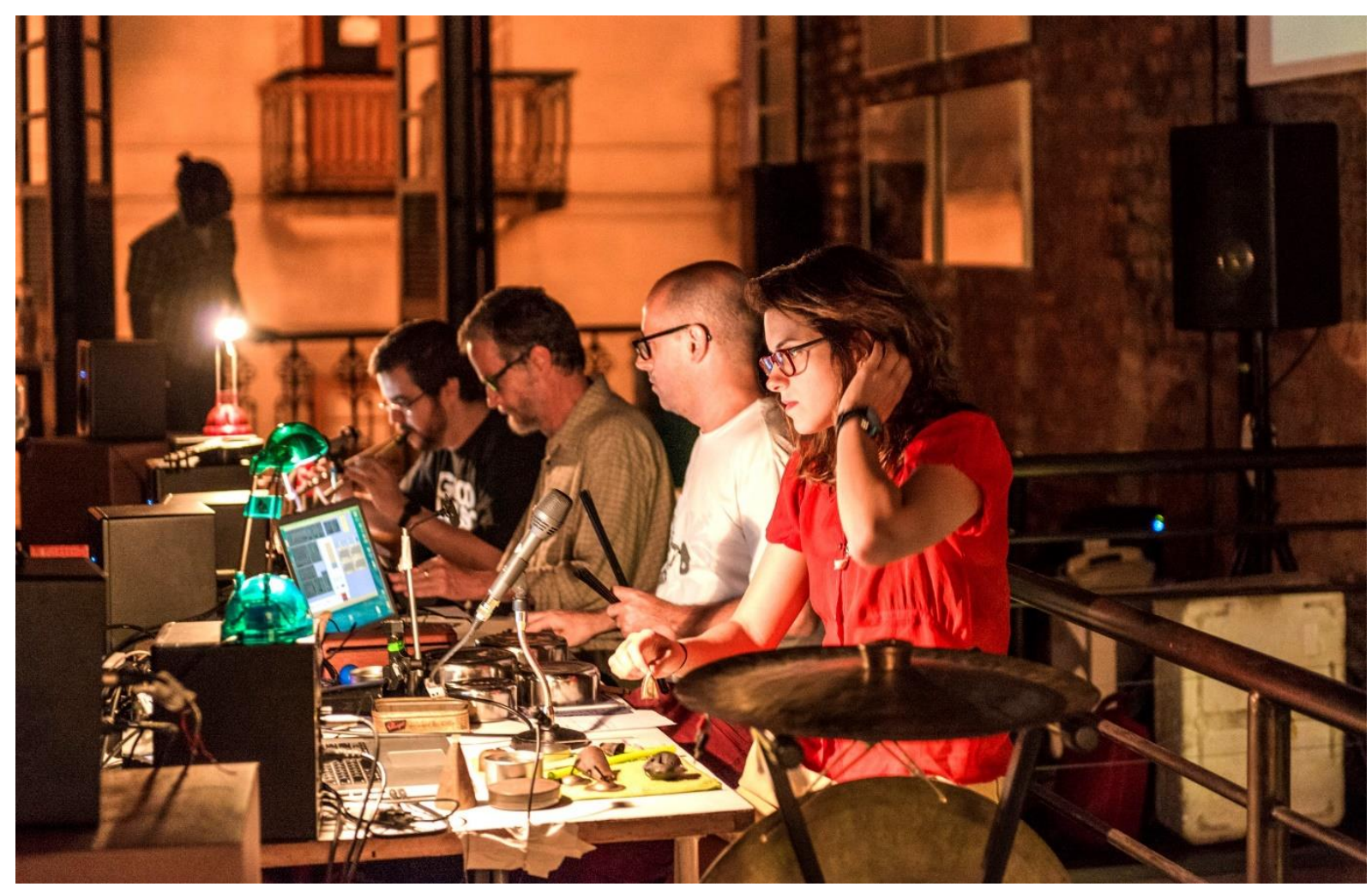

Figura 08: Apresentação do Personne em abril de 2014 durante o evento Encontros Carbônicos no Largo das Artes, Rio de Janeiro. 
O andamento de um jogo como esse acaba sempre dependendo de duas intenções já mencionadas que precisam ser compartilhadas entre os músicos: generosidade e confiança. Por um lado, cada músico sabe que seu parceiro pode, a qualquer momento, propor algo inesperado e todos devem abrir espaço para que isso aconteça. Por outro, essa abertura se funda na confiança de que cada membro saberá, a seu modo, lidar com o inesperado. Muitas vezes, a contribuição de cada músico é oferecer uma provocação que possa estimular os outros músicos a se reprogramarem. O que fornece coerência à performance é a escuta, já que as ações - ou poderíamos chamar de gestos - podem ser bastante diversas. Um loop maquínico pode se confrontar com o comportamento errático de objetos amplificados que produzem sons incontroláveis. Ou uma construção vocal acompanhada de ruídos corporais pode fornecer um contraponto a materiais sonoros pré-gravados e invariáveis. Se num conjunto instrumental tradicional há certa sintonia entre os tipos de articulação, sonoridade e modo de operação dos instrumentos envolvidos, no Personne isso é completamente descartado. Cada músico constrói sua ideia de instrumento e, com isso, instaura seu vocabulário de gestos sonoros possíveis. Nada que soe é incompatível, mas cada um tem que aprender a se reconfigurar todo o tempo para que a performance não estacione.

Embora o som esteja no cerne do trabalho do grupo, a projeção cênica também é fundamental. Daí a importância dos gestos. Não se trata aqui de uma teatralidade explícita, quer dizer, de ter nos gestos e ações uma intencionalidade narrativa. Isso diz respeito apenas à consciência da presença no palco e ao fato de que cada gesto se compõe com cada som que dele deriva. Refiro-me a uma dramaturgia que se constitui pela performance, pela presença e pela ação de cada um dos músicos. No caso da recriação da Symphonie pour un homme seul, por exemplo, nem sempre o que contava era a mimese sonora, no sentido acústico, da obra original de Schaeffer e Henry. Geralmente, as recriações de cada um dos movimentos da obra se apoiava muito mais nos gestos que provocavam os sons, na sua intensidade, na sua densidade, na sua distribuição no tempo.

Numa performance mais recente, realizada no Largo das Artes no Rio de Janeiro 5 (ver Fig. 08), quatro músicos, ao mesmo tempo em que atuavam em sintonia com

\footnotetext{
5 Performance realizada em 26 de abril de 2014 pelo Personne no Largo das Artes, Rio de Janeiro, como parte do evento Encontros Carbônicos. Atuaram nesta apresentação Alexandre Fenerich, Fernando Iazzetta, Lílian Campesato e Rodolfo Caesar. Um registro da performance pode ser visto em: https://www.youtube.com/watch?v=KUveD-vKnO4
} 
a trama sonora geral do espetáculo, mantinham também uma clara independência em relação aos seus modos particulares de atuação. Quer dizer, cada um trazia uma gestualidade própria e individual. Alguns tocavam pequenos objetos, como que criando um catálogo de possibilidades para sonificar aquilo que geralmente permanece em silêncio: latas, brinquedos, utensílios. Esses objetos, tal qual uma pequena banda musical, impõem, pela sua fisicalidade, aquilo que é possível tocar. Cada um deles demanda um gesto, uma energia específica, um esforço e uma técnica de manipulação próprios. Ao mesmo tempo, eram usados sons prégravados que podiam ser disparados por alguma interface eletrônica. Estando prégravados, esses sons estão irremediavelmente submetidos às suas estruturas inerentes, às suas morfologias acústicas. O aparelho eletrônico normaliza, achata os modos de produção sonora, já que um mesmo gesto pode desencadear os mais diferentes tipos de som. Ao mesmo tempo, isso traz agilidade, diversidade e regularidade que, dificilmente, podem ser alcançadas com os sons produzidos com instrumentos mecânicos, pela voz ou pelos objetos que eram acionados por percussão ou friç̧ão. Por essa razão, a percepção dos sons é reprogramada a cada vez que eles são inseridos na polifonia criada pelo grupo. Os gestos diferentes de cada um dos músicos complementam-se e chocam-se ao mesmo tempo.

As diferenças marcantes nos modos de articulação dos sons produzidos são um elemento essencial para garantir a individualidade da performance de cada músico, mas também funcionam como elemento de tensão fundamental para que se crie o jogo de encadeamento sonoro durante as performances.

Há em nossas performances um processo que difere de outras práticas semelhantes, como a improvisação livre, quando elaboradas por grupos de instrumentos tradicionais em que o controle se dá no nível da nota, que dizer, dos sons articulados individualmente e sequencialmente pelo músico em seu instrumento. No Personne o processo de construção está mais apoiado na produção de sons, imagens e gestos de características muito diferentes.

\section{Fechando o texto}

Se há alguma intenção nos textos apresentados aqui, esta intenção é a do diálogo, do compartilhamento da experiência criativa do grupo. Ao contrário do que muitas vezes se encontra em textos escritos por artistas que comentam suas próprias 
obras, não há pretensão de demonstrar que a criação artística do grupo decorre de um plano formal inicial, de um método pré-estabelecido ou de uma estratégia qualquer de filiação ou contraposição a esta ou àquela corrente. Antes, estes textos descrevem como uma rica teia de significados pode ser tecida a partir do encontro de artistas dispostos a compartilhar suas experiências musicais. Ou seja, a produção do Personne coincide com o que os próprios músicos podem trocar entre si. Mas reflete também um desejo de se descolar dos ambientes mais fechados e cristalizados em que a música de concerto se fixou - as salas de concerto, os festivais de música, os eventos promovidos pela (e para a) academia.

Os desdobramentos de um trabalho tão estimulante como o projeto de transcriação da Symphonie não se referem a um resultado que se queria alcançar de antemão, mas tão somente ao impulso pela descoberta, à curiosidade e ao comprometimento dos músicos. Transcrever os sons da Symphonie não é simplesmente uma tarefe musical, é um trabalho de invenção, que se inicia pela compreensão da obra de Schaeffer e Henry e passa obrigatoriamente pela exposição dessa obra ao entendimento que cada um dos participantes do Personne tem acerca da música de modo geral. É importante ressaltar a força desse processo, pois foi a partir dele que o trabalho realizado por colegas tornou-se um trabalho em grupo.

Os projetos que sucederam ao da Symphonie podem parecer um pouco mais vagos em sua proposta, mas mantiveram o mesmo espirito de experimentação a partir das contribuições individuais dos participantes. Os trabalhos, fortemente ligados com a imagem, claramente refletem o desejo de transpor as muretas que, comportadamente, representam o que é (ou o que geralmente se entende como) música e de ampliar as possibilidades de usos de materiais e estímulos sonoros dentro de um ambiente de performance. Não se trata, portanto, de colar música à imagem, mas de trabalhar sonoramente com as referências que temos acerca da arte de modo geral. Se isso resulta às vezes em algum traço de precariedade formal ou de inabilidade performática, é porque, já há algum tempo, descreditamos que o rigor técnico e a crença na formalização realmente sirvam como parâmetros de valoração aplicável a toda e qualquer produção artística. Esses traços, somados à efemeridade dos trabalhos, nos confere uma leveza que há muito abandonou outros nichos da música (especialmente a de concerto) e nos permite levar a sério tudo o que o que estamos descobrindo. 


\section{Referências Bibliográficas}

BABBITT, Milton. "Who cares if you listen", High Fidelity, VIII/2, February, 1958, 38-40, 126-127.

BENJAMIN, Walter. "O Autor como Produtor" In: Magia e Técnica, Arte e Política - Ensaios sobre literatura e história da cultura. São Paulo: Editora Brasiliense, 2012 (8. a edição).

COCCO, Giuseppe. KorpoBraz: por uma política dos corpos. Rio de Janeiro: Mauad X, 2014.

BORN, Georgina. Rationalizing Culture: IRCAM, Boulez and the Institutionalization of the musical avant-garde. Berkeley: University of California Press, 1995.

COMPAGNON, Antoine. Os cinco paradoxos da modernidade. Editora UFMG, 2.a Ed., 2010 (Ed. original: Éditions du Seuil, 1990).

FLUSSER, Vilém. Fenomenologia do Brasileiro: em busca de um novo homem. Rio de Janeiro: Editora da UERJ, 1998.

FLUSSER, Vilém. O Universo das Imagens Técnicas: o elogio da superficialidade. São Paulo: Anna Blume, 2008.

GADAMER, Hans-Georg. A Atualidade do Belo: a arte como jogo, símbolo e festa. Rio de Janeiro: Tempo Brasileiro, 1985. 


\section{Links}

- Apresentação da Symphonie pour un homme seul de Pierre Schaeffer \& Pierre Henry, Parque Lage, Rio de Janiero, em 16 de outubro de 2015:

- performance:

https://www.youtube.com/watch?v=OQOPHVTtio0

- ensaio:

https://www.youtube.com/watch?v=0mv4 oeG1IY

https://www.youtube.com/watch?v=5D7 tQ42M8s

- Apresentação do Personne no evento Encontros Carbônicos no Largo das Artes, Rio de Janeiro, 26 de abril de 2014

https://www.youtube.com/watch?v=KUveD-vKnO4 